\title{
Oncogenic osteomalacia
}

\author{
J MCCLURE, P S SMITH*
}

From the Department of Pathology, University of Manchester, and the *Division of Tissue Pathology, Institute of Medical and Veterinary Science, Adelaide, South Australia

SUMMARY Severe osteomalacia (confirmed by the examination of thin undecalcified bone biopsy sections) associated with hypophosphataemia developed in a 60 year old woman. A skeletal $x$-ray survey showed a lytic lesion in the right proximal femur, and this was curetted, showing a vascular tumour. The patient's symptoms improved almost immediately and serum phosphate concentrations returned to normal. Some time later the syndrome and the tumour recurred. The tumour was excised, and again the patient improved. Morphological examination of the tumour showed a lesion which closely resembled haemangiopericytoma. Review of published reports confirmed that most reported cases have been associated with "vascular" mesenchymal tumours both in intraosseous and extraosseous sites.

Throughout the world the most common cause of the osteomalacia and rickets syndrome is vitamin D deficiency due to dietary deprivation. There are, however, several other causes of the syndrome, which, although not necessarily common, are important: their recognition may lead to effective treatment; and an understanding of their pathogenetic mechanisms may give important insights into the processes of bone mineralisation. One such example is provided by the phenomenon of oncogenic osteomalacia. This seems to be a genuinely rare syndrome, in which osteomalacia is seen in association with a mesenchymal tumour (either intraosseous or extraosseous), and the osteomalacia heals when the tumour is removed. Concomitant hypophosphataemia commonly occurs.

Recently we had the opportunity of studying tumour and bone tissue from such a case and used light microscopical, ultrastructural, and undecalcified histological techniques to characterise the morphological features of the syndrome, which are detailed in this paper.

\section{Case report}

A 60 year old woman presented with increasing pain in both thighs associated with weakness, over two years. Latterly she developed increasing pain in both knees and ankles. She had been confined to a wheel

Accepted for publication 13 August 1986 chair for 18 months. There was no history of excess antacid ingestion or nutritional deficiency. There was no family history of bone disease.

Clinical examination showed a severe weakness in all pelvic girdle muscles. There was mild weakness of the shoulder girdle muscles. All lower limb movements were limited by pain. There was no wasting, diminution of reflexes, or impairment of sensation.

Serum calcium concentration was at $2.24 \mathrm{mmol} / \mathrm{l}$ (normal range $2 \cdot 20-2 \cdot 60$ ) but serum phosphate concentration at $0.40 \mathrm{mmol} / 1$ (normal range $0.80-1.30$ ) and that of serum 25 hydroxycholecalcified at $36 \mathrm{IU} / 1$ (normal range 40-160) were both low. Urinary calcium and phosphate concentrations were normal. The serum alkaline phosphatase activity (1326 IU/1, normal range $0-110)$ and the serum parathormone activity (7.8 IU/l, normal range $2 \cdot 0-6 \cdot 0)$ were raised. Continuing investigations showed a persistently low serum phosphate concentration coupled with normal serum calcium concentrations, high normal urinary calcium excretion, and low normal urinary phosphate excretion. This suggested a low tubular phosphate reabsorption. There was a low oral calcium absorption and a very high urinary hydroxyproline:creatinine ratio.

Oncogenic hypophosphataemic osteomalacia was presumptively diagnosed. A skeletal $x$-ray survey showed a lytic lesion in the right upper femur (fig 1). An operation was performed at which the femoral lesion was curetted, a bone biopsy was taken from the left anterior iliac crest for undecalcified histological study, and a muscle biopsy as taken from the right quadriceps femoris muscle. Postoperatively her serum 


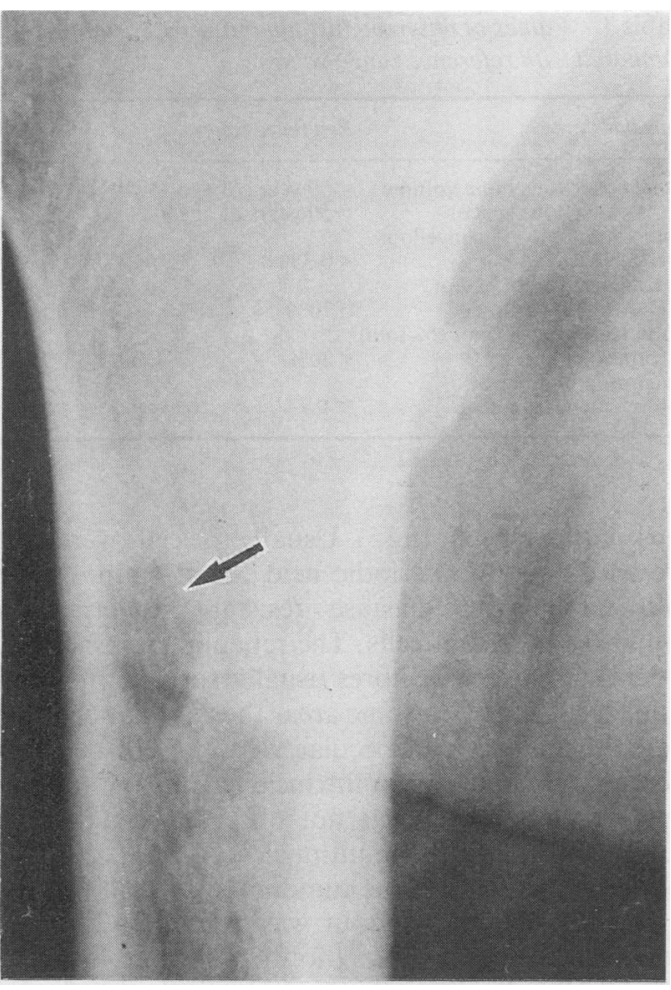

Fig 1 Radiograph of proximal femur. Lytic focus caused by intraosseous tumour is arrowed.

phosphate concentrations began to rise, urinary excretion fell, and the calcium absorption increased. She became mobilised and was able to walk. Her further improvement was complicated by pulmonary embolism for which she was successfully treated.

Nine months later her serum phosphate concentrations began to fall again and $x$-ray of the right upper femur showed a recrudescence of the lytic lesion. This area was excised en bloc (fig 2). After operation the serum phosphate concentration again returned to normal and she remains well at the time of writing.

\section{Pathological findings}

The bone biopsy specimen from the left iliac crest was fixed in buffered formalin containing a $1 \%$ solution of tetracycline for 48 hours. $^{1}$ Multiple, thin $(7 \mu \mathrm{m})$, undecalcified sections were cut after embedding in araldite. Sections were stained by the von Kossa technique with either the van Gieson method or haematoxylin and eosin as counter stains (fig 3 ). Using the van Gieson counterstained sections the total can-

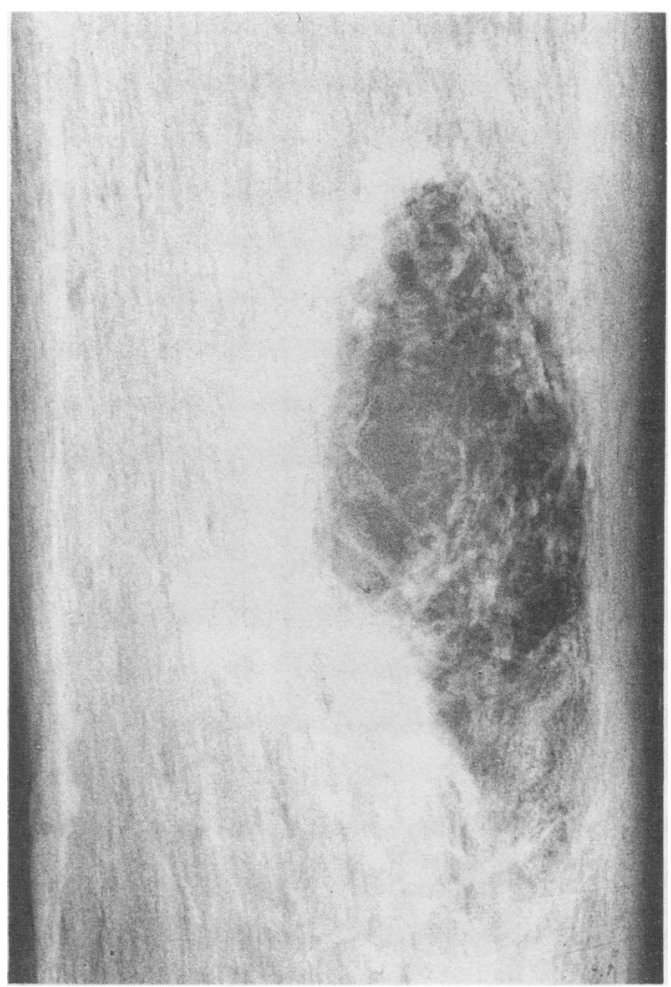

Fig 2 Contact radiograph of en bloc excision specimen showing recrudescent tumour.

cellous bone volume and the osteoid volume were estimated using a Quantimet 720 image analysis computer. The calcification fronts were shown by ultraviolet light fluorescence and their extent expressed as a percentage of the osteoid seams bearing a front. Total resorbing surfaces were estimated as the sum of the percentages of the trabecular surface occupied by either active (with an osteoclast) or inactive (without an osteoclast) resorption sites. An estimate of the thickness of the osteoid seams was obtained by counting the number of birefringent lamellae seen in polarised light and noting the maximum number.

Table 1 shows the results of these quantitative estimations. These show severe hyperosteoidosis with a severely reduced calcification front extent confirming the presence of severe osteomalacia.

The muscle biopsy specimen showed features consistent with a metabolic myopathy.

The curettings from the femoral lesion confirmed the presence of a tumour. This had a prominent vascular pattern composed largely (but not exclusively) of thin walled channels (fig 4). The intervening cellular proliferations were composed of round to oval 


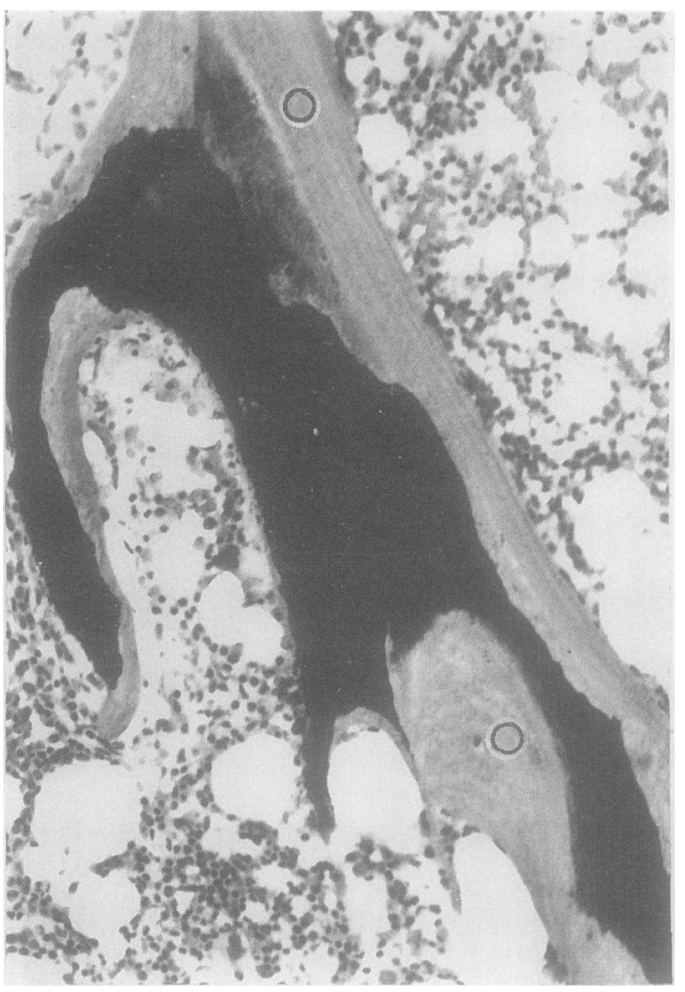

Fig 3 Undecalcified section of iliac bone. Mineralised zone (black) is greatly reduced in extent and osteoid $(O)$ is prominent. (von Kossa, haematoxylin and eosin.) × 100.
Table 1 Values of observed histoquantitative variables compared with reference range values

\begin{tabular}{llc}
\hline Variable & Reference range & Value \\
\hline $\begin{array}{c}\text { Total cancellous bone volume } \\
(\% \text { cancellous space) }\end{array}$ & $<50$ years of age 15-29\% & $15 \cdot 4$ \\
$\begin{array}{c}\text { Osteoid volume (\% cancellous } \\
\text { space) }\end{array}$ & $>50$ years of age $9-20 \%$ & \\
$\begin{array}{c}\text { Calcification front extent } \\
(\% \text { osteoid surface) }\end{array}$ & $>70 \%$ & $9 \cdot 5$ \\
$\begin{array}{c}\text { Total resorbing surface (\% total } \\
\text { trabecular surface) }\end{array}$ & $<20 \%$ & 15.4 \\
$\begin{array}{c}\text { Maximum number of } \\
\text { birefringent lamellae }\end{array}$ & $<4$ & 9 \\
\hline
\end{tabular}

fairly compact cells (fig 5). Usually the cells were quite crowded, but the periodic acid Schiff stain showed thin laminae of diastase resistant material surrounding groups of cells. The reticulin stains showed a delicate pattern of fibres usually surrounding individual cells (fig 6). In some areas the vascular channels were dilated. Bone trabeculae were present but these were mature and not an intrinsic part of the tumour. Osteoid elaboration was not observed. Small numbers of osteoclast like, multinucleated giant cells were scattered throughout the tumour.

The recrudescent tumour was excised en bloc and again there was a lytic (now somewhat loculated lesion). Histologically this was identical with the initial lesion.

Material from each specimen was fixed in glutaraldehyde, then fixed in osmium tetroxide and pro-

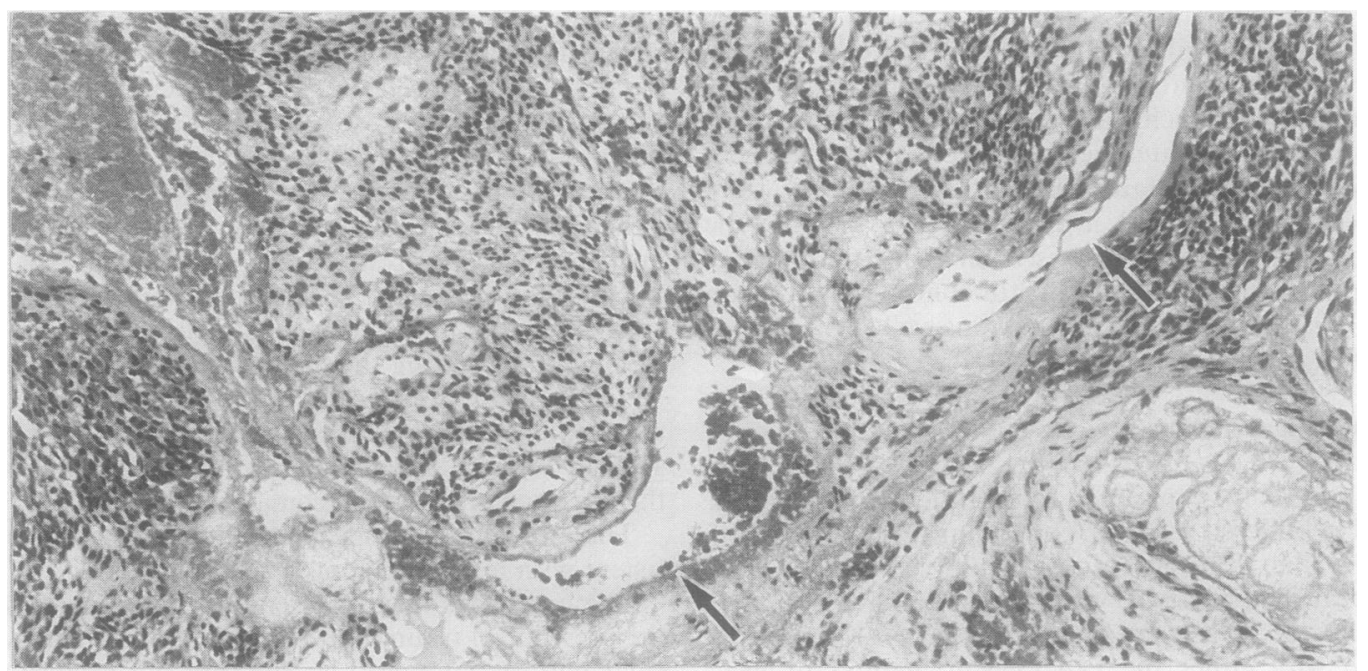

Fig 4 Photomicrograph of original tumour. Specimen obtained by curettage. Larger peripheral blood vessels are arrowed. (Haematoxylin and eosin.) $\times 100$. 


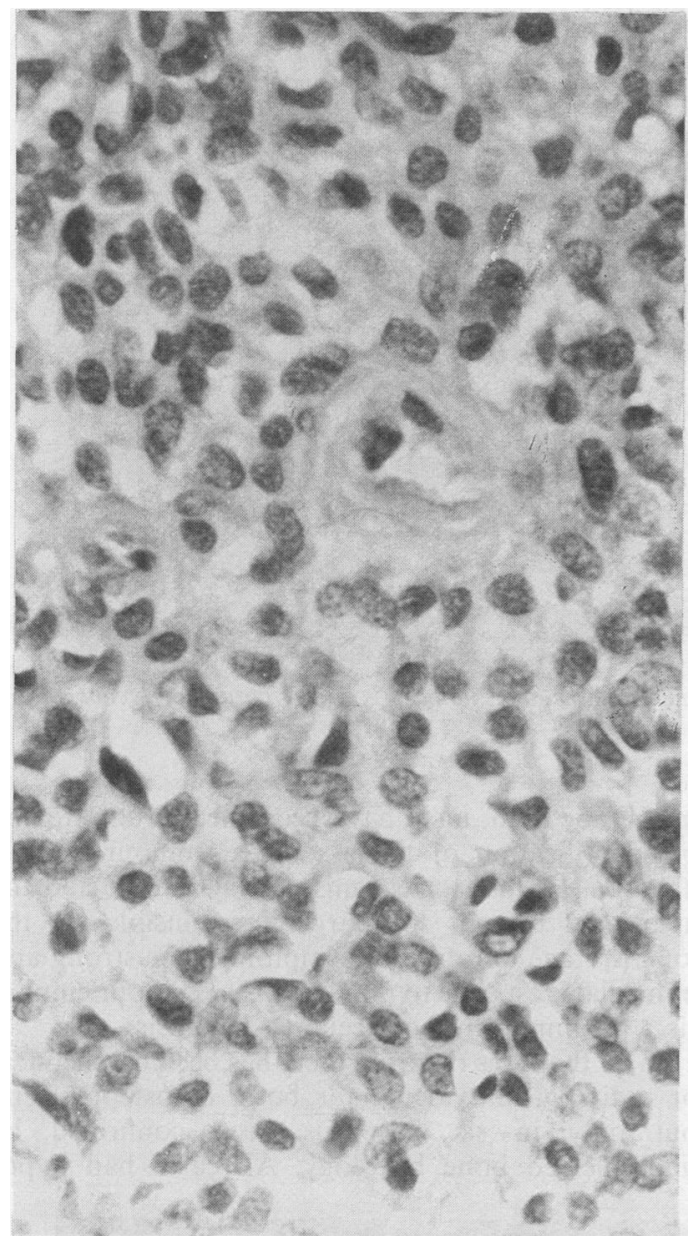

Fig 5 Perivascular disposition of tumour cells in recrudescent lesion. (Haematoxylin and eosin.) $\times 100$. cessed into Spurr's resin for ultrastructural study. This showed mainly spindle shaped cells scattered loosely through an amorphous stroma (fig 7). There were many thin walled blood vessels with surrounding cells which intermingled with vessel basement membranes (fig 8). The cytoplasmic outlines were irregular with many fine cell processes. There was a discontinuous external lamina around the outside of most cells (fig 9) and this seemed to resemble the amorphous stromal material, although this was less organised. Collagen was not seen. Cell nuclei were unremarkable. The cytoplasm contained fair numbers of rather large vesicles with thick limiting membranes (fig 10). These were concentrated beneath the plasma membrane and many seemed to be fused with the membrane. In places there were thin dense areas beneath the plasma membrane, especially in the cell processes. Junctional complexes were not observed, although in places plasma membranes were closely apposed.

\section{Discussion}

Undecalcified bone histology showed that the patient had a severe osteomalacia, due to hypophosphataemia. The association with an intraosseous tumour whose excision improved the biochemical and clinical abnormalities of the case indicates that this was an example of the oncogenic hypophosphataemic osteomalacia syndrome. The essential feature is that either an intraosseous or extraosseous tumour exerts an influence whereby serum, and, presumably, extracellular fluid phosphate, is depleted. This results in diminished calcification either at the calcification front in adult bone or in hypertrophic cartilage in the epiphyseal plate, thereby causing either osteomalacia or rickets depending on the age of the subject.

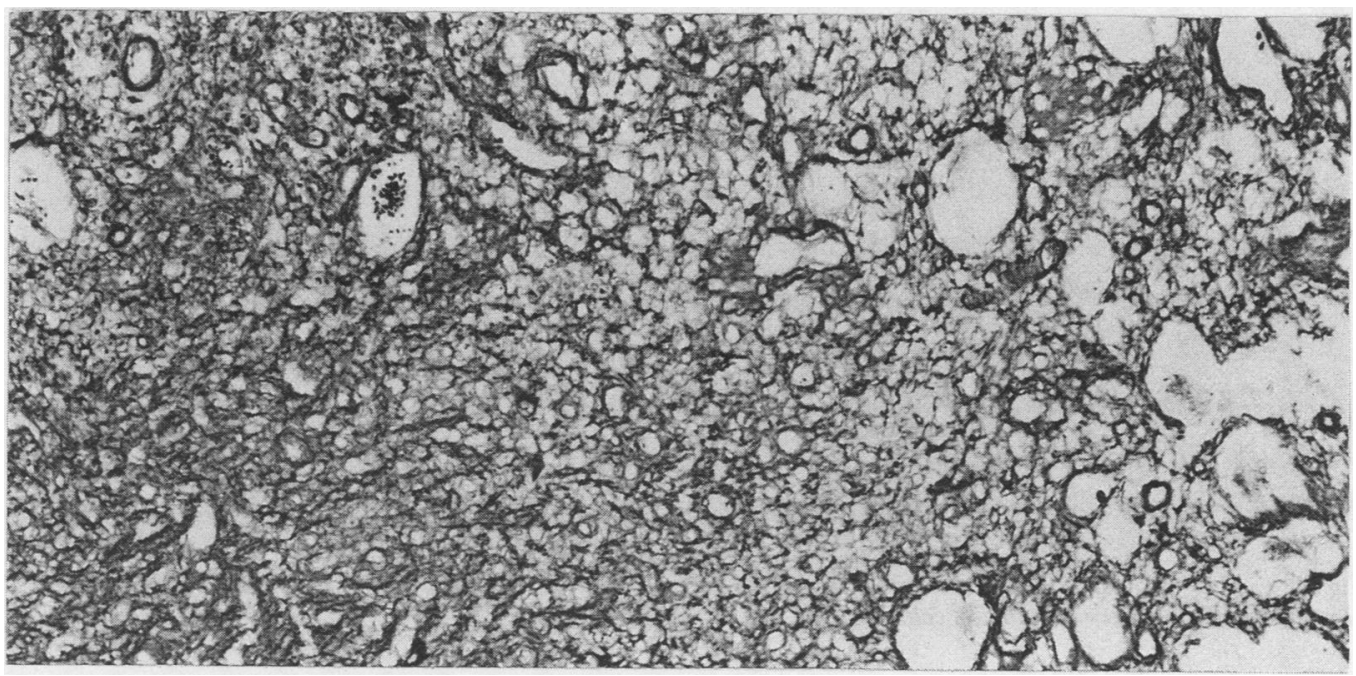

Fig 6 Reticulin pattern of excision specimen. $\times 100$. 


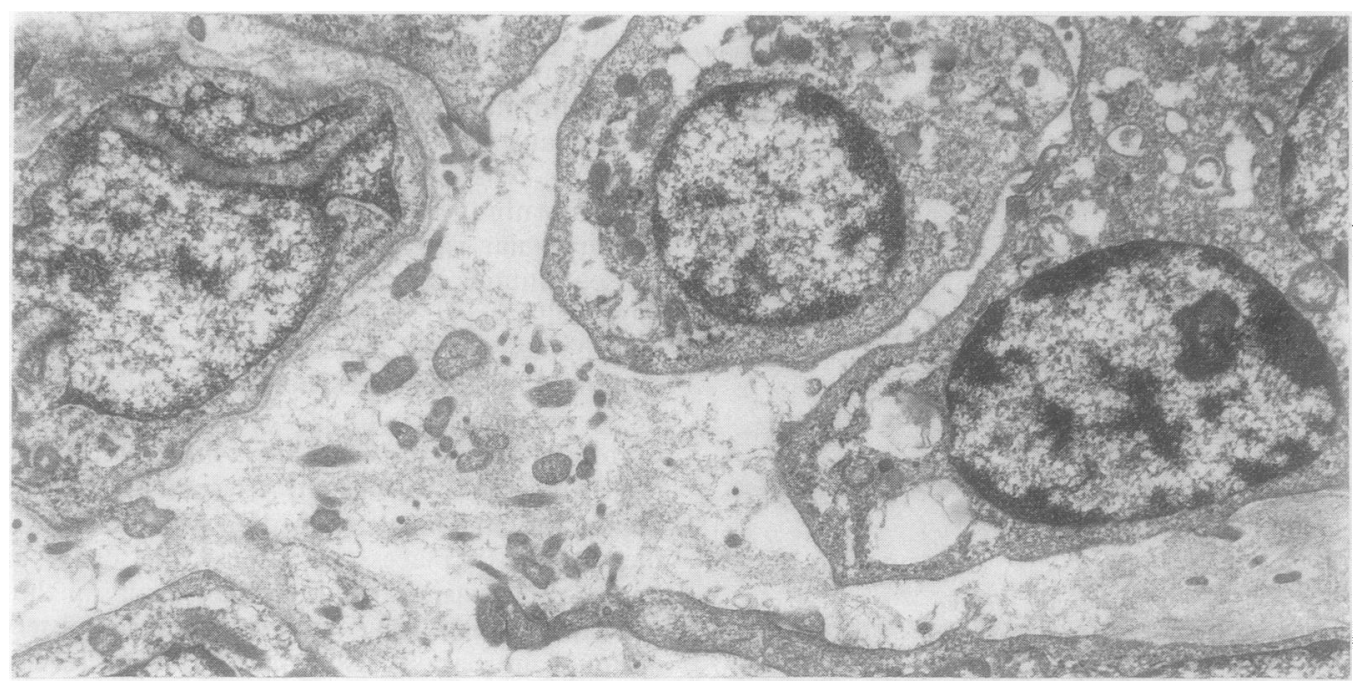

Fig 7 Electron micrograph of cellular focus in excision specimen. Intercellular material is like glycosaminoglycans. $\times$ 6500 .

That oncogenic hypophosphataemic osteomalacia is an unusual syndrome is illustrated by the fact that only 22 cases have been described. These comprise 12 males and 10 females with a mean age of 37 years (range 9-58). The average duration of symptoms is known from 12 cases and is an astonishingly long $5 \cdot 28$ years (range 0.6-17). Many of the patients were severely incapacitated by their osteomalacia and associated myopathy, being wheelchair-bound or bedridden. Although some cases have been controlled symptomatically by high doses of phosphate or vita- min D, or both, most have been successfully treated $\stackrel{\vec{D}}{\mathscr{N}}$ by identification of the associated tumour and its ablation. Failure to recognise the syndrome and the associated tumour was largely responsible for the long average duration of symptoms. The strong and immediate response to removal of the tumour emphasises the importance of accurate diagnosis.

In all the cases reported there has been biochemical $\overrightarrow{\vec{\theta}}$ or radiological evidence, or both, of osteomalacia, 3 but only in six has this been confirmed by undecalcified bone histology. All cases had hypo-

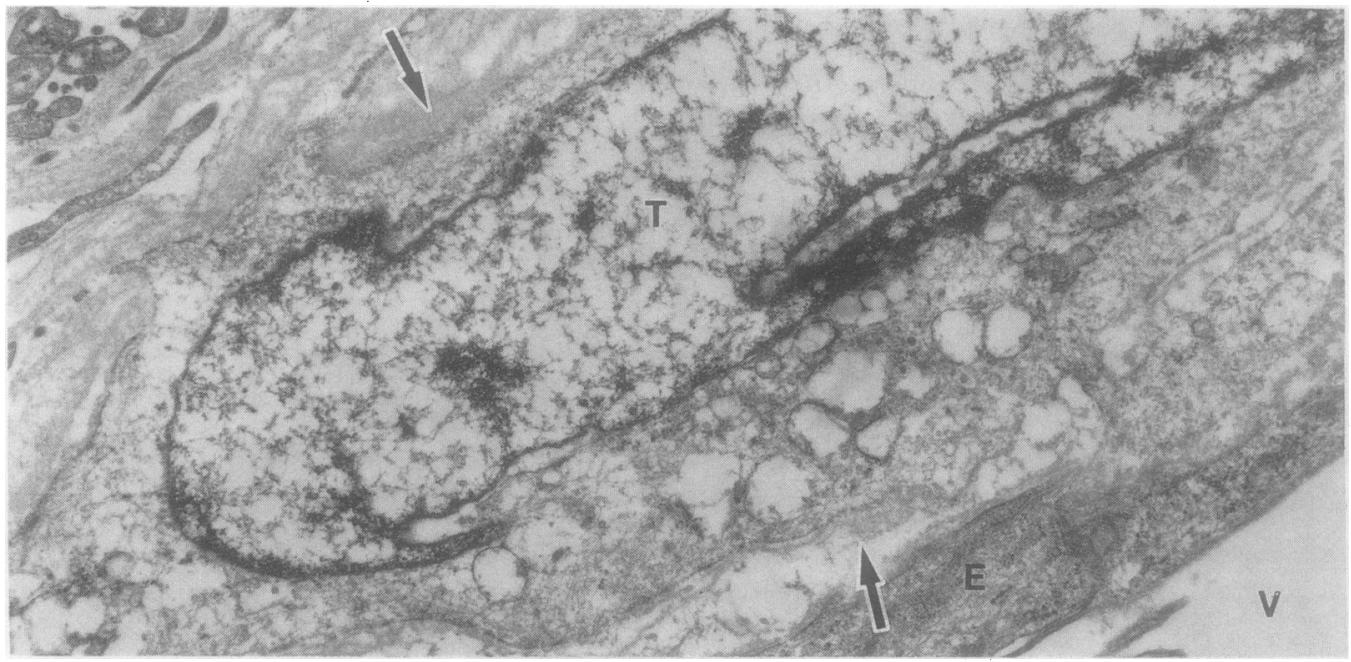

Fig 8 Tumour cell $(T)$ in close proximity to blood vessel, surrounded by vessel basement membrane (arrowed). $V=$ blood vessel lumen; $E=$ endothelial cells. $\times 6500$. 


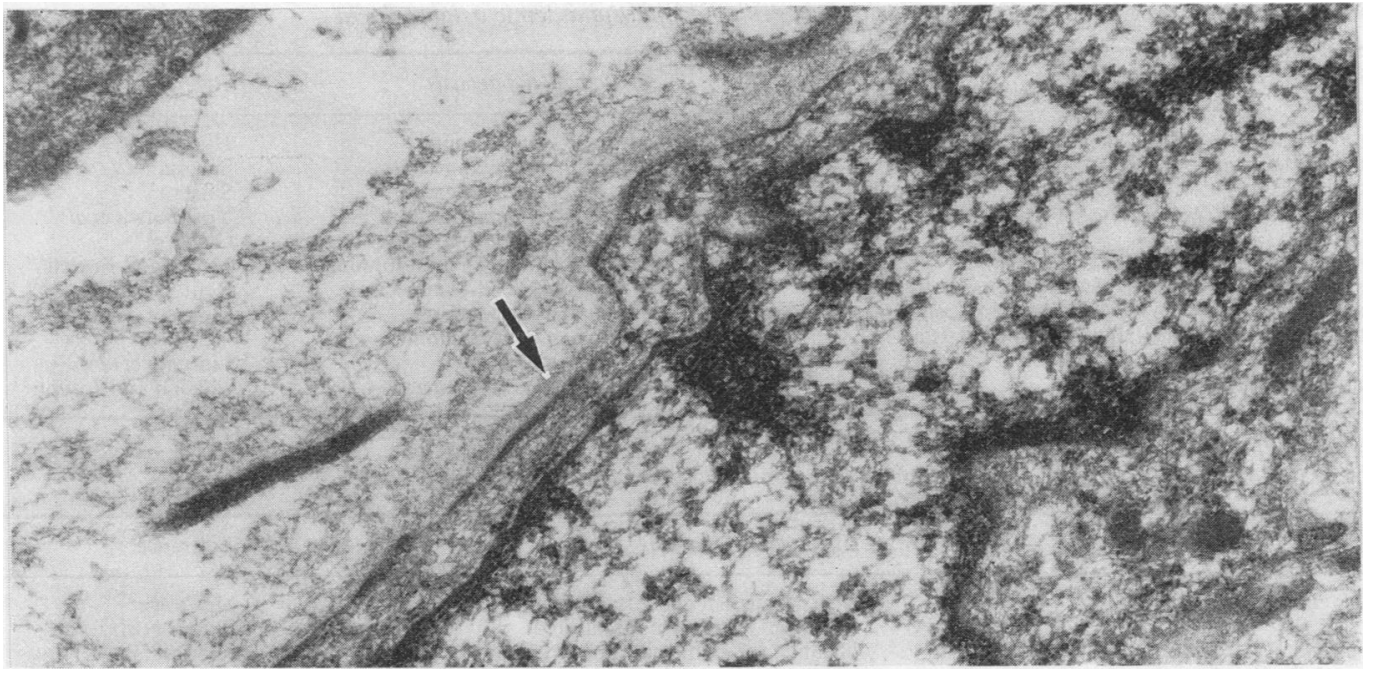

Fig 9 Discontinuous external lamina surrounding tumour cell is arrowed. $\times 19500$.

phosphataemia and 18 had hyperphosphaturia. Serum calcium concentrations were measured in 14 instances and were uniformly normal. Glycouria was observed in three cases and a low serum $1-\alpha$-25-dihydroxycholecalciferol concentration noted in one. Our patient had normal serum calcium concentrations but persistently low serum phosphate values. There was a low normal phosphate excretion, indicating a low tubular phosphate reabsorption. In addition there was a low serum 25-hydroxycholecalciferol concentration.

It is evidently important to consider the sites and nature of the associated tumours. These were either extraosseous or intraosseous in location. Table 2 shows the location of the extraosseous lesions and table 3 that of intraosseous. $\mathrm{McCance}^{2}$ reported the earliest case, and this does not seem to have been recognised as a true neoplasm. Table 4 gives a compilation of the various histological diagnoses applied to these lesions. Haemangiopericytoma is the most common diagnostic label. Evans and Azzopardi ${ }^{3}$ had the opportunity of examining the slides from several of the then reported cases and concluded that the tumours were a unitary entity, perhaps a variant of haemangiopericytoma. Considering the other histopathological labels that have been applied, several

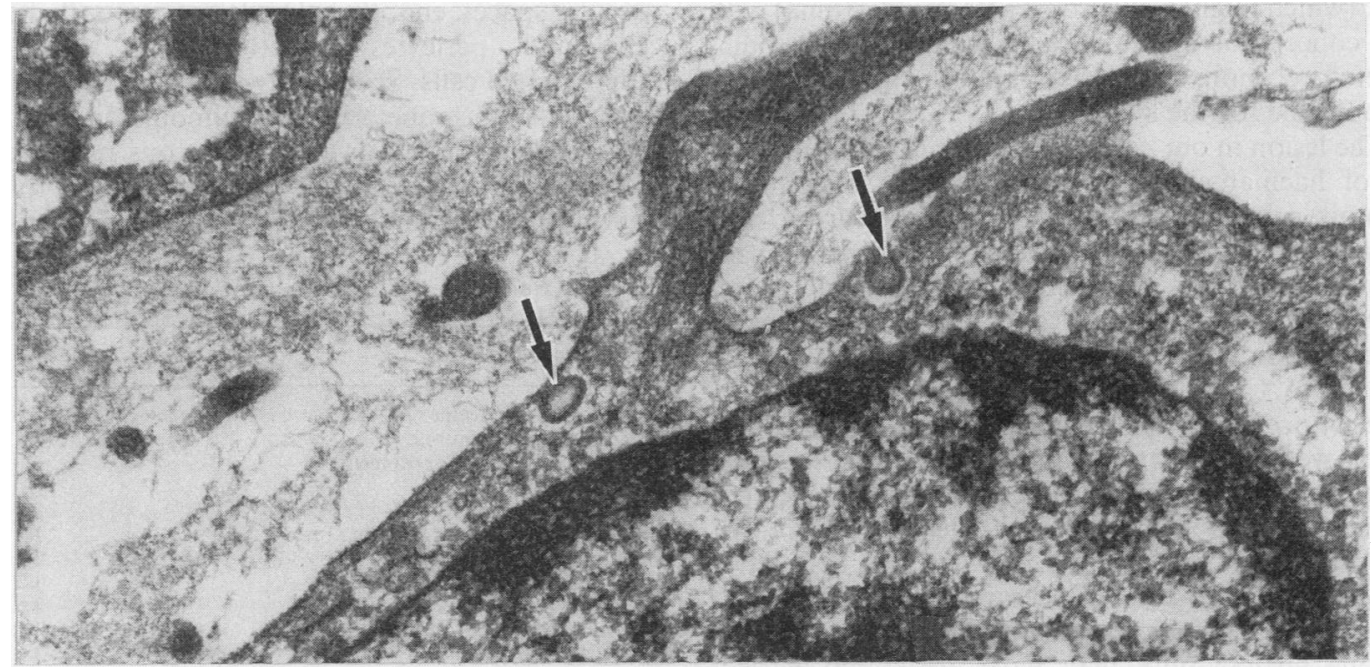

Fig 10 Intracytoplasmic sublamellar vesicles are arrowed. $\times 26000$. 
Table 2 Extraosseous tumours associated with oncogenic hypophosphataemic osteomalacia

\begin{tabular}{|c|c|c|}
\hline Site and gross appearances & Histological diagnosis & Reference \\
\hline $\begin{array}{l}\text { Left axilla and left infraclavicular area affecting scapula } \\
\text { Left groin hard mass }(30 \times 40 \mathrm{~mm}) \\
\text { Medial aspect right thigh just above knee in soft tissue } \\
\text { Behind left knee in soft tissues }(40 \times 25 \mathrm{~mm}) \\
\text { Pharynx } \\
\text { Subcutaneous lump in dorsal surface of right great toe }(10 \times 10 \mathrm{~cm}) \\
\text { Mass in anterior abdominal wall }(100 \mathrm{~mm} \text { in diameter }) \\
\text { Mass in soft tissues below right medial maleolus }(60 \times 40 \mathrm{~mm}) \\
\text { Soft tissue mass over medial aspect of right knee } \\
\text { Tumour in left nostril }\end{array}$ & $\begin{array}{l}\text { Malignant neurinoma } \\
\text { Sclerosing haemangioma } \\
\text { Sclerosing haemangioma } \\
\text { Cavernous haemangioma } \\
\text { Ossifying mesenchymal tumour } \\
\text { Ossifying mesenchymal tumour } \\
\text { Haemangiopericytoma } \\
\text { Haemangiopericytoma } \\
\text { Sclerosing haemangioma- } \\
\text { angiosarcoma } \\
\text { Haemangiopericytoma }\end{array}$ & 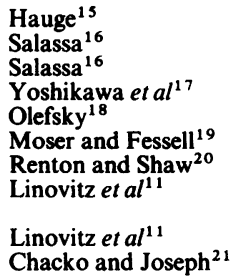 \\
\hline
\end{tabular}

Table 3 Intraosseous tumours associated with oncogenic hypophosphataemic osteomalacia

\begin{tabular}{|c|c|c|}
\hline Site & Histological diagnosis & Reference \\
\hline $\begin{array}{l}\text { Lower end of right femur } \\
\text { Rib } \\
\text { Upper end of left femur affecting the hip joint } \\
\text { Upper end of left femur } \\
\text { Right radius } \\
\text { Right distal ulna } \\
\text { Ethmoid bone } \\
\text { Right iliac bone } \\
\text { Fourth metacarpal } \\
\text { Upper one third shaft of humerus } \\
\text { Multiple lytic lesions of skull, pelvis, and ribs } \\
\text { Mandible }\end{array}$ & $\begin{array}{l}\text { Degenerate osteoid with trabecular structure } \\
\text { Giant cell reparative granuloma } \\
\text { ? Malignant giant cell tumour of bone } \\
\text { Distinctive mesenchymal tumour; variant of } \\
\text { haemangiopericytoma } \\
\text { Non-ossifying fibroma } \\
\text { Benign ossifying mesenchymal tumour } \\
\text { Haemangiopericytoma } \\
\text { Fibroblastic proliferation and numerous multinucleated } \\
\text { giant cells } \\
\text { Osteoblastoma } \\
\text { Osteoblastoma } \\
\text { Haemangiomas of bone } \\
\text { Giant cell tumour }\end{array}$ & 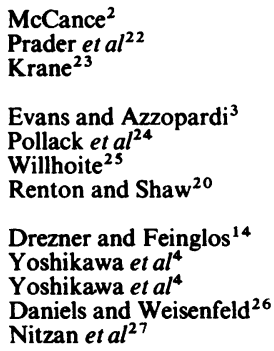 \\
\hline
\end{tabular}

could certainly have been haemangiopericytoma, the essential nature of the lesion being obscured by other features such as osteoid formation and giant cell aggregation. It is difficult, however, to reconcile the osteoblastomas described by Yoshikawa et al ${ }^{4}$ and McCance's degenerate osteoid with trabecular structure (which might well also be an osteoblastoma) with the concept of an obscured haemangiopericytoma. Therefore more than one tumour type may be responsible for the syndrome.

The lesion in our case conforms well to the diagnosis of haemangiopericytoma.This is an uncommon tumour, originally defined by Stout and Murray 5 and usually affecting soft tissues. ${ }^{67}$ Primary haemangiopericytoma of bone is exceptionally rare. Stout $^{8}$ noted two in a series of 197 . Marcial-Rojas ${ }^{9}$ described a case with metastases. Wold et al ${ }^{10}$ from the Mayo Clinic reported their experience with 15 cases. Formation of osteoid and giant cell accumulation were not described as a feature of these cases. Only one of the Mayo Clinic series was associated with hypophosphataemic osteomalacia. An important point made by Wold et al was that other tumours such as osteogenic sarcoma, synovial sarcoma, mesenchymal chondrosarcoma and malignant fibrous histiocytoma may have areas that closely resemble haemangiopericytoma, and adequate sam- pling is therefore necessary to ensure accurate diagnosis.

Evans and Azzopardi stated that they performed ultrastructural studies in their case but did not give details. Linovitz et al ${ }^{11}$ reported that their ultrastructural study showed a variegated pattern with vascular spaces, endothelial buds, rare smooth muscle cells and pericytes, together with less well differentiated cells. Specifically they could see no features of a hormone secreting tumour. In our case there were spindle cells with numerous processes, a discontinuous external lamina, and an amorphous non-fibrillar stroma. Subplasmalemmal densities

Table 4 No of cases with particular diagnostic label

\begin{tabular}{ll}
\hline Histological diagnoses & No \\
\hline Haemangiopericytoma & 5 \\
Sclerosing haemangioma & 3 \\
Ossifying mesenchymal tumour & 3 \\
Osteoblastoma & 2 \\
Cavernous haemangioma & 2 \\
Giant cell reparative granuloma & 1 \\
Malignant giant cell tumour & 1 \\
Giant cell tumour & 1 \\
Non-ossifying fibroma & 1 \\
Tumour like mass of degenerate osteoid & 1 \\
Fibroblastic proliferation with numerous giant cells & 1 \\
Malignant neurinoma &
\end{tabular}


were observed, but these could not be resolved into filaments. Although there has been some variation in the described ultrastructural features of reported cases of haemangiopericytoma, ${ }^{12}$ the features noted in the present case were entirely consistent with that diagnosis.

A distinctive feature of our case was the presence of large cytoplasmic vesicles surrounded by thick membrane and concentrated close to the plasmalemma. These vesicles were larger than conventional pinocytotic vesicles and have not been noted in previous reports of the ultrastructural features of haemangiopericytomas (most of which have been soft tissue lesions). It is tempting to postulate, but impossible to prove, that these might have represented an exocytotic (perhaps secretory) mechanism.

This then leads to a consideration of the way in which these associated tumours might be related to hypophosphataemic osteomalacia. The speculation has been that the tumours elaborate a peptide with an effect on the renal transport of phosphate. ${ }^{13}$ It has been further speculated that the hypothetical substance might be like parathormone-but lacking an action on bone cells. It might activate adenyl cyclase of the proximal convoluted tubule, thus impairing phosphate reabsorption. Against this Drezner and Feinglos ${ }^{14}$ found a deficiency of 1- $\alpha, 25$-dihydroxyvitamin $D_{3}$ in their patient, which, when given, was followed by resolution of the clinical and biochemical abnormalities. Excision of the tumour allowed treatment to be discontinued. Their hypothesis therefore was that these tumours produce a substance which inhibits 25-hydroxycholecalciferol-1-hydroxylase activity, causing a decrease in the synthesis of 1 , 25-dihydroxy vitamin $D_{3}$, the deficiency of which is thought to cause renal phosphate wasting and the sequence of events leading to osteomalacia and myopathy.

These are as yet hypotheses as few of these interesting lesions have been studied in detail. Despite the absolute rarity of the syndrome it is of true clinical importance, because its recognition has profound implications for early and successful treatment.

\section{References}

$1 \mathrm{McCl}$ ure $\mathrm{J}$. The demonstration of calcification fronts by in vivo and in vitro tetracycline labelling. J Clin Pathol 1982; 35:1278-82.

2 McCance RA. Osteomalacia with Looser's nodes (Milkman's syndrome) due to a raised resistance to vitamin $D$ acquired about the age of 15 years. $Q J$ Med 1947;14:33-46.

3 Evans DJ, Azzopardi JG. Distinctive tumours of bone and soft tissue causing acquired vitamin-D-resistant osteomalacia. Lancet 1972;i:353-4.

4 Yoshikawa S, Nakamura T, Takagi M, Imamura T, Okano K,
Sasaki S. Benign osteoblastoma as a cause of osteomalacia. A report of two cases. J Bone Joint Surg 1977;59(B):279-86.

5 Stout AP, Murray MR, Hemangiopericytoma: a vascular tumour featuring Zimmermann's pericytes. Ann Surg 1942;116:26-33.

6 Enzinger FM, Smith BH. Hemangiopericytoma. An analysis of 106 cases. Hum Pathol 1976;7:61-82.

7 McMaster MJ, Soule EH, Ivins JC. Hemangiopericytoma. A clinicopathologic study and long-term follow-up of 60 patients. Cancer 1975;36:2232-44.

8 Stout AP. Tumors featuring pericytes: glomus tumor and hemangiopericytoma. Lab Invest 1956;5:217-23.

9 Marcial-Rojas RA. Primary hemangiopericytoma of bone. Review of the literature and report of the first case with metastases. Cancer 1960;13:308-11.

10 Wold LE, Unni KK, Cooper KI, Sim FH, Dahlin DC. Hemangiopericytoma of bone. Am J Surg Pathol 1982;6:53-8.

11 Linovitz RJ, Resnick D, Keissling P, et al. Tumor-induced osteomalacia and rickets: a surgically curable syndrome. J Bone Joint Surg 1976;58(-A):419-23.

12 Battifora Hector. Hemangioperictyoma: ultrastructural study of five cases. Cancer 1973;31:1418-32.

13 Harrison HE. Oncogenous rickets: possible elaboration by a tumour of a humoral substance inhibiting tubular reabsorption of phosphate. Paediatrics 1973;52:432-4.

14 Drezner MK, Feinglos MN. Osteomalacia due to $1 \alpha$, 25-dihydroxycholecalciferol deficiency. Association with a giant cell tumor of bone. J Clin Invest 1977;60:1046-53.

15 Hauge BN. Vitamin D resistant osteomalacia. Acta Med Scand 1956;153:271-82.

16 Salassa RM, Jousey Jennifer, Arnaud CA. Hypophosphatemic osteomalacia associated with "nonendocrine tumours". New Engl J Med 1970;283:65-70.

17 Yoshikawa S, Kawabata M, Hatsuyama Y, Hosokawa O, Fujita T. Atypical vitamin-D resistant osteomalacia. $J$ Bone Joint Surg 1964;46(A):998-1007.

18 Olefsky J, Kempson R, Jones H, Reaven G. Tertiary hyperparathyroidism and apparent "cure" of vitamin-D-resistant rickets after removal of an ossifying mesenchymal tumour of the pharynx. New Engl J Med 1972;286:740-5.

19 Moser CR, Fessell J. Rheumatic manifestations of hypophosphatemia. Arch Intern Med 1974;134:674-8.

20 Renton P, Shaw DG. Hypophosphatemic osteomalacia secondary to vascular tumors of bone and soft tissue. Skeletal Radiol 1976:1:21-4.

21 Chacko V, Joseph B. Osteomalacia associated with haemangiopericytoma. J Indian Med Assoc 1981;76:173-5.

22 Prader von A, Illig Ruth, Uehlinger E, Stalder G. Rachitis infolge knochentumors. Helv Paediatr Acta 1959;14:554-65.

23 Krane SM. Case records of the Massachusetts General Hospital. New Engl J Med 1965;273:494-504.

24 Pollack JA, Schiller AL, Crawford JD. Rickets and myopathy cured by removal of a nonossifying fibroma of bone. Paediatrics 1973;52:364-71.

25 Willhoite DR. Acquired rickets and solitary bone tumor: the question of a causal relationship. Clinical Orthopaedics and Related Reseach 1975;109:210-1.

26 Daniels RA, Weisenfeld I. Tumorous phosphaturia osteomalacia. Report of a case associated with multiple hemangioma of bone. Am J Med 1979;67:155-9.

27 Nitzan DW, Marmary Y, Azaz V. Mandibular tumor-induced muscular weakness and osteomalacia. Oral Surg 1981; 52:253-6.

Requests for reprints to: Dr J McClure, Department of Histopathology, University Hospital School of Medicine, Nell Lane, West Didsbury, Manchester M20 8LR, England. 